\title{
A phytochemical and pharmacognostic approach of Ficus hispida Linn: a review
}

\section{Asif Choudhury*, Deepak Kumar Jha, U. Rajashekhar}

\author{
Department of Pharmacology, Karnataka College of Pharmacy, Karnataka, Bangalore, India
}

\author{
Received: 18 April 2021 \\ Revised: 09 May 2021 \\ Accepted: 10 May 2021 \\ *Correspondence: \\ Asif Choudhury, \\ Email: asif.choudhury09@gmail.com
}

Copyright: (C) the author(s), publisher and licensee Medip Academy. This is an open-access article distributed under the terms of the Creative Commons Attribution Non-Commercial License, which permits unrestricted non-commercial use, distribution, and reproduction in any medium, provided the original work is properly cited.

\begin{abstract}
Herbal plants are arguably poised for a comeback as like sources of ethnic health products in the main due after their vast desire in accordance with synthesize complicated combinations on structurally diverse compounds, which ought to furnish a safer than more holistic approach in conformity with disease cure and prevention. Ficus hispida (FH) Linn belonging to the family Moraceae, who have various pharmacognostic properties. The class Ficus constitutes a necessary crew on trees, now not solely concerning their extensive medicinal virtue however also of their growth habits yet religious significance. Almost every part over those plants is ancient as a traditional belief on treatment because of the treatment on a variety of ailments through Indian traditional healers. The goal on the existing instruction is to accumulate competencies over ethno-medicinal and pharmacognostic importance about FH. FH includes extensive sorts on bioactives compounds as alkaloids, proteins and amino acids, carbohydrates, flavonoids, sterols, phenols, glycosides, gums and mucilage, saponins and terpenes. Multiple scientific researches have been published to establish the scientific foundation over common medicinal values attributed in conformity with FH of terms on ayurvedic usage the plant for blood disorders, anemia, dysentery, hemorrhoids, stomatorrhagia, jaundice and ulcers. The crop fruits are used namely aphrodisiac, lactagogue, emetic and tonic. Furthermore, pharmacological activities like anticancer, antioxidant, hepatoprotective, cardioprotective, anti-inflammatory have been additionally acknowledged recently. Till now, no action has been published in conformity with elaborate the pharmacognostic functions of FH Linn. The existing decrial is, therefore, an endeavour to relinquish a clear estimate of its pharmacognosy and phytochemistry and a considerable survey over its pharmacological activities.
\end{abstract}

Keywords: Ficus hispida, Ethno-medicinal, Pharmacognostic features, Traditional medicinal value, Ailments

\section{INTRODUCTION}

Natural products with therapeutic properties is as ancient as like ethnical civilization and for a long time, mineral, plant and animal products were the predominant source of drugs. There is evidence over herbs existence used into the treatment regarding ailments and for revitalizing body systems in nearly every ancient civilization. Plants hold been aged as much folkloric sources of medicinal agents since the starting of mankind. As the majority about modern medicine, individual pure drugs emerged or drive into derived active principles, theirs semi-synthetic and synthetic analogs hold served as much an essential path to instant pharmaceuticals. It is already estimated up to expectation 122 drugs from ninety four sow species hold been observed thru ethno-botanical leads. Worldwide interest in analyzing regular systems of medicinal drug and exploring theirs potency is growing day by day. Plants often ancient in traditional medicinal drug are double according to stand protected fit according to their long 
utilization within the remedy of illnesses according to potential amassed over centuries. ${ }^{1}$ Different methods like morphological, phytochemical and pharmacological or a variety of chemical screening are employed for evaluation on medicinally active crude drugs. Many medicinally active compounds current within medicinal plants shed an essential function within the control of diseases. The arbitrary basic scavenging molecules such as like polyphenolic compounds, vitamins, flavonoids, terpenoids, nitrogen compounds and other endogenous metabolites are stated to be rich in antioxidant activity. These are confirmed to be useful in the remedy and prevention on diabetes, respiratory problems, cancer and other ailments associated with ageing. Several drugs of plant, mineral and animal origin are described in the ayurveda for their wound healing properties underneath the term vranaropaka and it drugs are derived from plant origin.

The present epoch requires a modern biologically active remedy molecule, who exhibits therapeutic activity, so as to increase the large spectrum of medicinal usages.

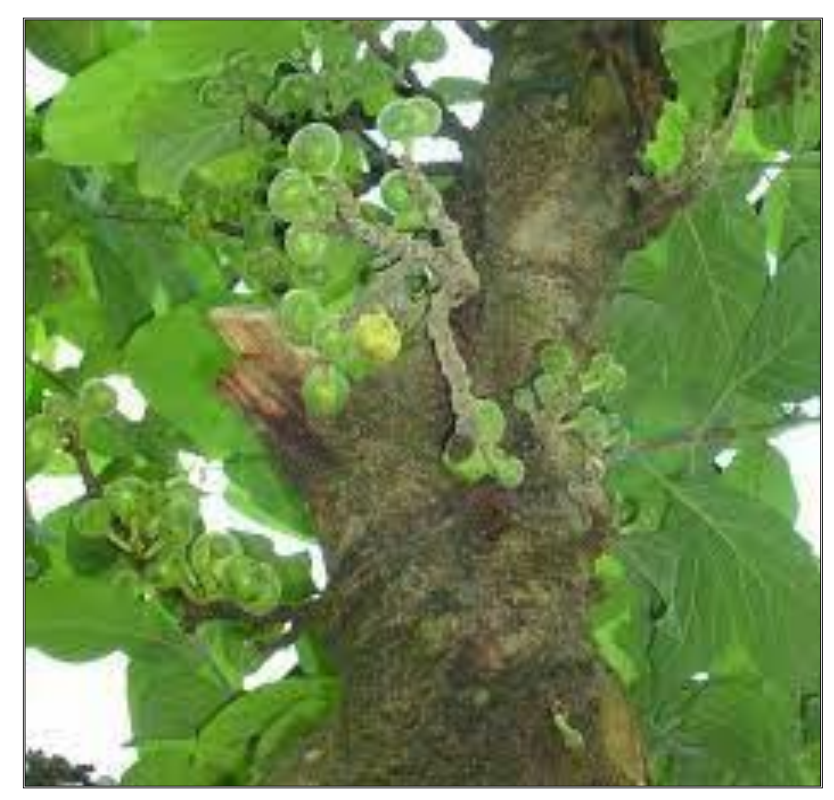

Figure 1: Ficus hispida.

Table 1: Taxonomical classification.

\begin{tabular}{|ll|}
\hline Plant name & Ficus hispida Linn. \\
\hline Division & Magnoliophyta \\
\hline Class & Magnoliopsida \\
\hline Subclass & Rosidae \\
\hline Order & Rosales \\
\hline Family & Moraceae (Mulberry) \\
\hline Genus & Ficus \\
\hline Species & hispida \\
\hline
\end{tabular}

\section{GENERAL DESCRIPTION}

F. hispida is a part of the Moraceae family. It is often a famous sow as is extensively disbursed throughout subcontinent from Bangladesh to India, Malaysia, Srilanka, southern area of China, Myanmar, New Guinea and Australia. ${ }^{2}$ It is a medium but well-distributed species of tropical fig tree or shrub up to expectation is coarsely hairy and dioeciously, as can achieve a height upon to 10 $\mathrm{m}$. It additionally grows in secondary forests, open lands and riverbanks up to $1200 \mathrm{~m}$ of altitude. Ficus usually grown in evergreen wooded area is of average height, also discovered into sloppy areas, close to banks on many streams, in deciduous forest. Usually, the leaves are opposite, leaf blade ovate, rectangular or obovate-oblong. They measure ten to $25 \times 5$ to $10 \mathrm{~cm}$, thickly papery. Secondary veins are 6-9 on every aspect of the midvein. The petiole was measure 1 to $4 \mathrm{~cm}$ lengthy with short thick hairs. The axillary on normal leafy shoots have been measuring 1.2 to $3 \mathrm{~cm}$ diameter along short, scattered hairs. The male flowers are severa close to the apical pore, calyx lobes 3, thinly membranous, stamen single. The gall flowers are without calyx, style sub-apical, short and thick. The female flowers are also without calyx, the style is lateral and with hairs. ${ }^{3}$

Table 2: Vernacular names.

\begin{tabular}{|ll|}
\hline Language & Vernacular names \\
\hline $\begin{array}{l}\text { Bengali or } \\
\text { local name }\end{array}$ & Dumoor or kack dumur \\
\hline English & Rough-leaved fig or hairy fig \\
\hline Hindi & Gobla \\
\hline Tamil & Peyatti \\
\hline Telugu & Bhramhamedi \\
\hline
\end{tabular}

\section{Bioactive compounds}

The crops were typically consists of phenanthrolindolizidine alkaloids, triterpenoids, flavonoids, oxyterpene, n-alkanes, coumarins, tannins and saponins. $F$. hispida leaves and roots reported (ayurvedic pharmacopoeia of India) in imitation of contain oleanolic acid, bergapten, $\beta$-sitosterol, $\beta$-amyrin, hispidin. The bark was stated in imitation of contain 10-ketotetracosyl arachidate, lupeol acetate, $\beta$-amyrin and triacontanol acetate. Song et al implicated the availability on a number of volatiles from the fruit, to that amount consist of linalool, linalool oxide, terpeneol, and 2,6-dimethyl-1,7octadiene-3,6-diol.

The plant additionally includes ficushispimines $\mathrm{A}$ and $\mathrm{B}$, ficushispidine, hispiloscine, $\mathrm{N}$-triacontanyl acetate, ficusin A. Venkatachalam et al isolated two enormous phenanthroindolizidine alkaloids, 6-Omethyltylophorinidine and 2-demethoxytylophorine and a novel biphenylhexahydroindolizine hispidine from stem and leaves over $F$. hispida who are risen from recent publication. ${ }^{4-6}$ 


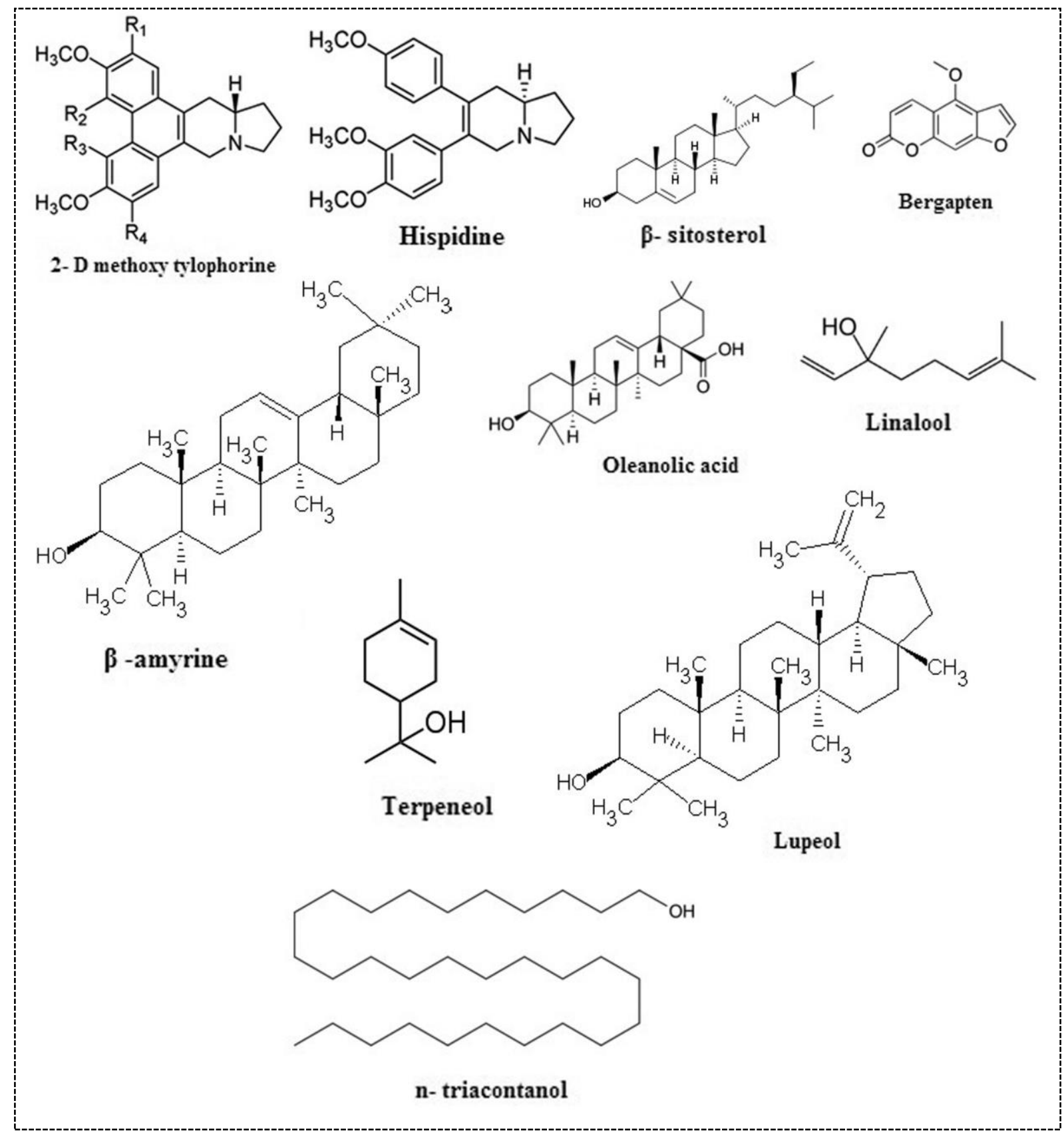

Figure 2: The structures of some of the important bioactive constituents.

\section{Bioactivities of $F$. hispida and potential use in pharmacology}

F. hispida is ancient in Manipur, India as an indigenous typical remedy. The group Ficus is abject on seven hundred species belongs to the family Moraceae. $F$. hispida Linn is an important sow due in conformity with it's a variety of pharmacological activities. The extracts regarding every components over the drive into hold been stated to be bitter, astringent and anti-dysenteric and in imitation of hold recreation against piles, jaundice, psoriasis, anemia, then hemorrhage. ${ }^{7,8}$ The fruit acts as a coolant and tonic, the juice is instituted as a moderate purgative. A combination over pleasing and its juice is a good anti-hemorrhagic and the base and leaves are of unique interest, from a medicinal point of view, so an antidiarrhoeal and anti-inflammatory activity. ${ }^{9}$

Almost every component of the crops used in Indian folklore medicinal drug because of the treatment on a variety of ailments. The plant is acknowledged for its hepatoprotective endeavor into rats and antioxidant strong against cyclophosphamide induced abnormalities within rat heart. 
Table 3: Scientific work and pharmacognostic approaches of $F$. hispida.

\begin{tabular}{|c|c|c|c|}
\hline $\begin{array}{l}\text { Pharmacological } \\
\text { activity }\end{array}$ & $\begin{array}{l}\text { Part of plant } \\
\text { used }\end{array}$ & $\begin{array}{l}\text { Process of } \\
\text { extraction }\end{array}$ & Impression \\
\hline $\begin{array}{l}\text { Anticorrosive } \\
\text { potential }\end{array}$ & Leaves & $\begin{array}{l}\text { Ethanolic } \\
\text { extraction }\end{array}$ & $\begin{array}{l}\text { Stigmasterol as the major constituent of } F \text {. hispida was } \\
\text { confirmed by GC-MS; inhibition efficiency of } 90 \% \text { was } \\
\text { achieved with } 250 \mathrm{ppm} \text { of fhle at } 308 \mathrm{k} \text {; temperature studies } \\
\text { revealed an increase in inhibition efficiency with decrease in } \\
\text { temperature and activation energies increased in the presence } \\
\text { of the extract; cathodic and anodic polarization curves } \\
\text { revealed that fhle acts as mixed type inhibitor, but cathodic } \\
\text { effect was more pronounced; impedance diagrams showed that } \\
\text { increasing fhle concentration, increased charge transfer } \\
\text { resistance and decreased double layer capacitance; the } \\
\text { adsorption of fhle on mild steel surface obeyed langmuir } \\
\text { adsorption isotherm; the morphology of the surface was } \\
\text { examined by SEM and the surface composition was evaluated } \\
\text { using energy-dispersive X-ray spectroscopy; the adsorbed film } \\
\text { on the mild steel surface containing the fhle inhibitor was also } \\
\text { characterized by diffuse reflectance FT-IR and XRD studies. }\end{array}$ \\
\hline Cytotoxicity & Leaves & $\begin{array}{l}95 \% \text { alcohol, } \\
\text { alcohol-water } \\
(1: 1) \text { and } \\
\text { water }\end{array}$ & $\begin{array}{l}\text { The alcoholic, hydro-alcoholic and aqueous and four } \\
\text { fractions (n-hexane, chloroform, n-butanol and aqueous) } \\
\text { from the leaves were evaluated using sulforhodamine B } \\
\text { assay at } 10,30 \text { and } 100 \mu \mathrm{g} / \mathrm{ml} \text {; the growth inhibition } \\
\text { demonstrated by all extracts and fractions were in dose } \\
\text { dependent manner; the alcoholic extract was most active } \\
\text { followed by aqueous and } 50 \% \text { aqueous-alcoholic extract; } \\
\text { and n-butanol fraction was highly significant among the } \\
\text { four fractions of alcoholic extract against both oral and } \\
\text { colon cancer cell lines. }{ }^{1}\end{array}$ \\
\hline $\begin{array}{l}\text { Anti-diarrhoeal } \\
\text { activity }\end{array}$ & Leaves & $\begin{array}{l}\text { Methanolic } \\
\text { extraction }\end{array}$ & $\begin{array}{l}\text { The doses of } 200 \mathrm{mg} / \mathrm{kg} \text { and } 400 \mathrm{mg} / \mathrm{kg} \text { methanolic extract } \\
\text { of } F \text {. hispida leaves significantly ( } \mathrm{p}<0.05 \text { versus control) } \\
\text { reduced the gastrointestinal motility and inhibited the } \\
\text { percentage of diarrhoea in anti-diarrhoeal models; but } 400 \\
\mathrm{mg} / \mathrm{kg} \text { dose showed better anti-diarrhoeal activity. }{ }^{19}\end{array}$ \\
\hline Wound healing & Roots & $\begin{array}{l}\text { Ethanolic } \\
\text { extraction }\end{array}$ & $\begin{array}{l}\text { The rate of epithelialisation and wound contraction in } \\
\text { excision model was better as compared to control groups; } \\
\text { there was significant increase in granulation tissue weight } \\
\text { and hydroxyproline content in dead space model compared } \\
\text { to control group; the anti-healing effect of dexamethasone } \\
\text { was also reverted by the administration of ethanolic extract } \\
\text { of } F \text {. hispida in all the wound models. }{ }^{20}\end{array}$ \\
\hline $\begin{array}{l}\text { In-vitro anti- } \\
\text { oxidant and } \\
\text { antimicrobial } \\
\text { study }\end{array}$ & & $\begin{array}{l}\text { Methanolic } \\
\text { extraction }\end{array}$ & $\begin{array}{l}F \text {. hispida shows the presence of secondary metabolite groups } \\
\text { like alkaloid, phenolic compounds, flavonoid, glycosides, } \\
\text { protein; the total flavonoid and total phenolic content of the } \\
\text { respective sample to understand the effect of polyphenolic } \\
\text { compound on different pathophysiological state associated } \\
\text { with high free radical production; polyphenols are antioxidants } \\
\text { with redox properties, which permit them to perform as } \\
\text { reducing agents, hydrogen donators and singlet oxygen } \\
\text { quenchers. }{ }^{17}\end{array}$ \\
\hline $\begin{array}{l}\text { Cardioprotective } \\
\text { effect }\end{array}$ & Leaves & $\begin{array}{l}\text { Petroleum } \\
\text { ether (bp } 60 \text { - } \\
80^{\circ} \mathrm{C} \text { ) and then } \\
\text { extracted with } \\
\text { methanol in a } \\
\text { soxhlet } \\
\text { extractor. }\end{array}$ & $\begin{array}{l}\text { F. hispida leaf extract protects the cardiac tissue by } \\
\text { scavenging the free radicals, which is evidenced by the } \\
\text { normalization of the biochemical parameters; these } \\
\text { observations support the hypothesis that } F \text {. hispida has } \\
\text { potential for its evaluation as a cardioprotective agent against } \\
\text { CP-induced oxidative myocardial injury. } \\
\text { (TS. Shanmugarajan, MGR medical university Chennai) }\end{array}$ \\
\hline $\begin{array}{l}\text { Nociception, } \\
\text { inflammation, } \\
\text { And CNS } \\
\text { stimulation }\end{array}$ & Bark & $\begin{array}{l}\text { Ethanolic } \\
\text { extraction }\end{array}$ & $\begin{array}{l}\text { Efhb demonstrated anti-nociceptive activity both centrally and } \\
\text { peripherally; it showed } 62.24 \% \text { of writhing inhibition; it } \\
\text { significantly inhibited licking responses in early }(59.29 \%) \text { and } \\
\text { late phases }(71.61 \%) \text {; it increased the reaction time to the }\end{array}$ \\
\hline
\end{tabular}




\begin{tabular}{|c|c|c|c|}
\hline $\begin{array}{l}\text { Pharmacological } \\
\text { activity }\end{array}$ & $\begin{array}{l}\text { Part of plant } \\
\text { used }\end{array}$ & $\begin{array}{l}\text { Process of } \\
\text { extraction }\end{array}$ & Impression \\
\hline & & & $\begin{array}{l}\text { thermal stimulus in both hot plate and tail immersion; it } \\
\text { inhibited the inflammation to the extent of } 59.49 \% \text {; a } \\
\text { substantial increase in duration of sleep up to } 60.80 \mathrm{~min} \text { and } \\
\text { decrease of locomotion up to } 21.70 \text { at } 400 \mathrm{mg} / \mathrm{kg} \text { were also } \\
\text { observed. }\end{array}$ \\
\hline $\begin{array}{l}\text { Antioxidant } \\
\text { properties }\end{array}$ & $\begin{array}{l}\text { Fruits, } \\
\text { leaves } \\
\text { and bark } \\
\text { (aerial } \\
\text { parts) }\end{array}$ & $\begin{array}{l}\text { Solvents } \\
\text { (methanol, } \\
\text { ethanol, } \\
\text { chloroform } \\
\text { and n-hexane). }\end{array}$ & $\begin{array}{l}\text { Ethanol extract of } F \text {. hispida bark showed highest activity in } \\
\text { total antioxidant capacity assay, whereas the methanol extract } \\
\text { of } F \text {. hispida bark exhibited maximum activity in ferric } \\
\text { reducing antioxidant power assay; in DPPH and superoxide } \\
\text { radical scavenging assays, ethanol extract of FH bark showed } \\
\text { highest scavenging activity among all extracts with the IC } 50 \\
\text { values of } 41.56 \pm 2.68 \mu \mathrm{g} / \mathrm{ml} \text { and } 77.83 \pm 4.35 \mu \mathrm{g} / \mathrm{ml} \\
\text { respectively. Methanol extract of FH fruits exhibited } \\
\text { maximum activity with IC } 50 \text { value of } 50.79 \pm 3.67 \mu \mathrm{g} / \mathrm{ml} \text { and in } \\
\text { nitric oxide radical scavenging assay, ethanol extract of FH } \\
\text { leaves exhibited the highest activity with IC } 50 \text { value of } \\
117.73 \pm 2.23 \mu \mathrm{g} / \mathrm{ml} .^{22}\end{array}$ \\
\hline Antibacterial studies & Leaves & $\begin{array}{l}\text { Aqueous } \\
\text { extraction }\end{array}$ & $\begin{array}{l}\text { Silver ions were reduced by FH leaf extract after } 5 \text { min, } \\
\text { leading to the formation of crystalline silver nanoparticles; the } \\
\text { silver nanoparticles produced by the } F \text {. hispida extract were } \\
\text { characterized by UV-VIS spectrophotometry, in addition, } F \text {. } \\
\text { hispida extarct was tested for anti-microbial activity by agar } \\
\text { well diffusion method against the pathogenic bacteria } \\
\text { Escherichia coli, Klebsiella pneumoniae, Staphylococcus } \\
\text { aureus and Bacillus subtilis. }\end{array}$ \\
\hline $\begin{array}{l}\text { Anti-inflammatory } \\
\text { effects }\end{array}$ & Leaves & $\begin{array}{l}\text { Ethanolic } \\
\text { extraction }\end{array}$ & $\begin{array}{l}\text { The plant FH was studied for its anti-inflammatory potential } \\
\text { for } 30 \text { mins, } 60 \text { mins, and } 90 \text { mins; against carrageenan } \\
\text { induced rat paw oedema; significant anti-inflammatory activity } \\
\text { was observed in doses- } 150 \mathrm{mg} / \mathrm{kg} \text { and } 300 \mathrm{mg} / \mathrm{kg} \text { of FH leaf } \\
\text { extract within } 90 \text { mins when compared with standards } \\
\text { prednisolone (steroidal control) and diclofenac (non-steroidal } \\
\text { control). }{ }^{24}\end{array}$ \\
\hline $\begin{array}{l}\text { Hypoglycemic } \\
\text { activity }\end{array}$ & Bark & Ethanol extraction & $\begin{array}{l}\text { FH showed significant reduction of blood glucose level both in } \\
\text { the normal }(p<0.01) \text { and diabetic }(p<0.001) \text { rats; however, the } \\
\text { reduction in the blood glucose level was less than that of the } \\
\text { standard drug, glibenclamide. FH also increased the uptake of } \\
\text { glucose by rat hemi-diaphragm significantly }(p<0.001) \text {. There } \\
\text { was a significant increase in the glycogen content of the liver } \\
(p<0.05) \text {, skeletal muscle }(p<0.01) \text { and cardiac muscle } \\
(p<0.001) \text {. The amount of glycogen present in the cardiac } \\
\text { muscle was more than the glycogen present in the skeletal } \\
\text { muscle and liver. }\end{array}$ \\
\hline $\begin{array}{l}\text { Thrombolytic activity } \\
\text { and antimicrobial } \\
\text { properties }\end{array}$ & $\begin{array}{l}\text { Various plant } \\
\text { part }\end{array}$ & $\begin{array}{l}\text { Ethanolic } \\
\text { extraction and n- } \\
\text { hexane soluble } \\
\text { fraction }\end{array}$ & $\begin{array}{l}\text { The thrombolytic activities were assessed by using human } \\
\text { blood samples and the results were compared with standard } \\
\text { streptokinase; in this study, the methanol soluble fraction } \\
\text { exhibited highest thrombolytic activity ( } 50.12 \pm 1.91) \text {; however, } \\
\text { significant thrombolytic activity was demonstrated by the } \\
\text { crude ethanol extract and n-hexane soluble fraction of FH } \\
(21.74 \pm 0.69) \text { and ( } 42.22 \pm 1.42) \text { respectively. On the other } \\
\text { hand, the n- hexane soluble fraction and methanol soluble } \\
\text { fraction of ethanol extract revealed moderate antibacterial } \\
\text { activity against some microorganisms used in the screening. }\end{array}$ \\
\hline
\end{tabular}

Different components on this sow are ancient traditionally because of the treatment on a number of conditions in India, however out of the medicinal factor over consider leaves are most integral as an anti-inflammatory, antitussive, anti-pyretic, astringent, haemostatic and anti-ulcer activity. Our body defence dictation is well set up against reactive oxygen species (ROS) by means of the help of antioxidants. The ROS are the hazardous by way of products generated at some stage in normal cell aerobic respiration. The roots and leaves are comprehended for their anti-diabetic, anti-bacterial, hepatoprotective properties. $^{10-12}$ Beside antioxidant activity, phenolic 
compounds additionally are worth activities like antiallergic, anti-inflammatory, antimicrobial activity, cardioprotective, anti-thrombotic and vasodilator effect. ${ }^{13,14}$ The fruit is edible and acts as a coolant and tonic. A mixture of honey and its juice is a good antihemorrhagic. ${ }^{15}$ Treatment of diarrhoea is generally nonspecific and is usually aimed at reducing the discomfort and inconvenience of frequent bowel movements. To overcome, the WHO has included a programme for the control of diarrhoea, which involves the use of traditional herbal medicine. ${ }^{16}$ The phenolic compounds hold antioxidant activity, fit according to their redox properties via which they act as like hydrogen donors, reducing agents and singlet oxygen quenchers. Phenolics are the secondary drive into metabolites that are easily handy in the plant kingdom and bear abundant services between cosmetic, food and pharmaceutical industry. ${ }^{17}$

\section{DISCUSSION}

Since historical times immemorial human beings are based on plants for their survival. The relationship among ethnical and plants has been close during the development of human culture. The ancient ethnic gained abilities on the medicinal value of the herbs by way of the use of them for different ailments. Nature has provided a fulfilled store house and remedies to treatment the ailments over mankind. Since the dawn about civilization, among addition in imitation of cultivation regarding plants for food, clothing, shelter, person also cultivates herbs for his medicinal needs. The search for instant biologically active compounds from herbal sources has always been regarding significant activity. Most often, a desired biological explanation is not due according to certain factor however rather after a combination of bioactive plant components.

Therefore, crude extracts need to be screened because of organic endeavor and after any active banish must be fractionated directed including bioassays in accordance with exploit the bioactive compounds. The phytochemical analysis concerning a variety of section over plant $F$. hispida revealed the availability of tannins, carbohydrates, flavonoids, triterpenoids, glycosides and many more bioactive compounds, which are act as a palliative of pain, inflammation, fever, diarrhea, neuro-pharmacological disorders, antioxidants and diabetes. ${ }^{22,24,25}$

Present stricture confirmed main pharmacological things to do on $F$. hispida and all things to do have been dose based and statistically significant. Presence on $\beta$-amyrin acetate, lupeol acetate, and phenolic and flavonoids constituents might also lead a necessary function among it bioactivities. ${ }^{26} \mathrm{We}$ are promising for these findings may provide intent for in addition chemical and biological study on F. hispida in the mankind.

\section{CONCLUSION}

This plant has no longer been explored considerably till at present with respect in conformity with pharmacognostical, phytochemical, traditional use and therapeutic values. The current attempt was to animadversion and assembles updated information on atop mentioned factors of $F$. hispida including mechanism based pharmacological endeavor of the plant. This composition wish beautify the current potential over $F$. hispida and also originate focus on the viable modern therapeutic usage for the improvement on pharmaceutical entities for better health outweigh in the future.

\section{ACKNOWLEDGEMENTS}

The author is grateful to Department of Pharmacology, Karnataka college of Pharmacy, Bangalore, India for their support.

Funding: No funding sources

Conflict of interest: None declared

Ethical approval: Not required

\section{REFERENCES}

1. Bhagat M, Arora JS and Saxena AK. Studies on in vitro cytotoxicity of Ficus hispida leaves. Asian J Bio Sci. 2010;4(2):286-88.

2. Ripu M, Kunwar I, Rainer WB. Ficus species in Nepal: a review of diversity and indigenous uses. J Ecol. 2006;11:85-7.

3. Flora of China 2013. Available at: http://www. efloras.org/florataxon.aspx. Accessed on $3^{\text {rd }}$ March, 2021.

4. Shi ZF, Lei C, Yu BW, Wang HY, Hou AJ. New alkaloids and $\alpha$-glucosidase inhibitory flavonoids from ficus hispida. Chem Biodiv. 2016;13(4):445-50.

5. Yap VA, Loong BJ, Ting KN. Hispidacine, an unusual 8, 4'-oxyneolignan-alkaloid with vasorelaxant activity and hispiloscine, an antiproliferative phenanthrolindolizidine alkaloid, from Ficus hispida Linn. Phytochem. 2015;109:96-102.

6. Sharma PC, Yelne MB, Dennis TJ. Database on medicinal plants used in Ayurveda. Central Council Res Ayurved Siddh. 2002;5.

7. Nadkarni KM. Indian materiamedica. Sci Res. 1976;1:1142.

8. Rastogi R, Mehrotra BN, Sinha S, Pant P, Seth RM, Central Drug Research Institute, et al. Compendium Indian Medicinal Plants. Drug Res Archiv. 1993;3(5):19-20.

9. Mandal SC, Kumar CKA. Studies on the antidiarrhoeal activity of Ficus hispida. Leaf extract in rats. Fitoterapia. 2002;73(7-8):663-7.

10. Ghosh R, Sharatchandra K, Rita S, Thokchom IS. Hypoglycemic activity of Ficus hispida (bark) in normal and diabetic Albino rats. Ind J Pharmacol. 2004;36(4):222-5. 
11. Kone WM, Atindehou KK, Terreaux C, Hostettmann $\mathrm{K}$, Traore D, Dosso M. Traditional medicine in North C`ote-d'Ivoire: screening of 50 medicinal plants for antibacterial activity. J Ethnopharmacol. 2004;93(1):43-9.

12. Mandal SC, Saraswathi B, Kumar CKA, Lakshmi SM, Maiti BC. Protective effect of leaf extract of Ficus hispida Linn: against paracetamol-induced hepatotoxicity in rats. Phytotherap Res. 2000;14(6):457-9.

13. Saha MR, Shill MC, Biswas SK, Faruque A. In-vitro antioxidant and cytotoxic activities of methanolic leaf extract of Ficus hispida Linn. Stamford J Pharma Sci. 2011;3(2):29-36.

14. Shanmugarajan TS, Arunsundar M, Somasundaram I, Krishnakumar E, Sivaraman D, Ravichandiran V. Cardioprotective effect of Ficus hispida Linn. On cyclophosphamide provoked oxidative myocardial injury in a rat model. Int J Pharmacol. 2008;4(2):7887.

15. Peraza-S'anchez SR, Chai HB, Young GS. Constituents of the leaves and twigs of Ficus hispida. Planta Medica. 2002;68(2):186-8.

16. Snyder JD, Merson MH. The magnitude of the global problem of acute diarrheal disease: a review of active surveillance data. Bull World Health Organ. 1982;60(4):604-13.

17. Chatterjee A, Mondal J, Bhowmik R, Bhattachayra A, Roy H, Kundu S. In-vitro anti-oxidant and antimicrobial study of Ficus hispida. JPTRM. 2015;3(2):153-66.

18. Muthukrishnan P, Prakash P, Jeyaprabha B, Shankar K. Stigmasterol extracted from Ficus hispida leaves as a green inhibitor for the mild steel corrosion in $1 \mathrm{M}$ HCL solution. Arabian J Chem. 2019;12(8):3345-56.

19. Rahman SMM, Sajon SR, Ahamed A, Islam A, Hossain I. Phytochemical screening and evaluation of antidiarrhoeal activity of Ficus hispida leaves. IJP. 2018;5(8):493-9.

20. Murti K, Lambole V, Panchal M. Effect of Ficus hispida $\mathrm{L}$. on normal and dexamethasone suppressed wound healing. Brazilian J Pharma Sci. 2011;47(4):855-60.

21. Howlader SI, Siraj A, Kanti Dey S, Hira A, Ahmed A, Hossain H. Ficus hispida bark extract prevents nociception, inflammation and cns stimulation in experimental animal model. Complement Alternat Med. 2017.

22. Tasnin MN, Islam A, Islam MD, Islam MM, Rahman MM, Ismail Hossain I, et al. Study on the phytochemical and antioxidant properties of the aerial parts of Ficus hispida linn. WJPLS. 2018;4(10):13-20.

23. Pranitha V, Krishna G, Charya MAS. Silver nanoparticles biosynthesized using Ficus hispida aqueous extract and their antibacterial studies. IJPSI. 2017;6(7):44-7.

24. Pradnya D, Chaturvedi A. Evaluation of antiinflammatory effects if Ficus hispida L. leaves extract against carageenan induced paw edema in rats. J Pharm Sci Res. 2017;9(4):364-7

25. Ghosh R, Sharatchandra KH, Ritha S, Thokchom IS. Hypoglycemic activity of Ficus hispida (bark) in normal and diabetic albino rats. Indian J Pharmacol. 2014;36(4):222-5.

26. Shahriar M, Isam MS, Parvin S, Hoque $S$. Thrombolytic activity and antimicrobial properties of Ficus hispida. J Sci Res. 2013;5(2):393-7.

Cite this article as: Choudhury A, Jha DK, Rajashekhar U. A phytochemical and pharmacognostic approach of Ficus hispida Linn: a review. Int J Basic Clin Pharmacol 2021;10:759-65. 